August 2007

\title{
The Istanbul Pogrom of 6-7 September 1955 in the Light of International Law
}

Alfred de Zayas

Follow this and additional works at: https://digitalcommons.usf.edu/gsp

\section{Recommended Citation}

de Zayas, Alfred (2007) "The Istanbul Pogrom of 6-7 September 1955 in the Light of International Law," Genocide Studies and Prevention: An International Journal: Vol. 2: Iss. 2: Article 4.

Available at: https://digitalcommons.usf.edu/gsp/vol2/iss2/4

This Articles is brought to you for free and open access by the Open Access Journals at Digital Commons @ University of South Florida. It has been accepted for inclusion in Genocide Studies and Prevention: An International Journal by an authorized editor of Digital Commons @ University of South Florida. For more information, please contact digitalcommons@usf.edu. 


\title{
The Istanbul Pogrom of 6-7 September 1955 in the Light of International Law
}

\author{
Alfred de Zayas \\ Geneva School of Diplomacy
}

The Istanbul pogrom (sometimes referred to as Septemvriana) was a governmentinstigated series of riots against the Greek minority of Istanbul in September 1955. It can be characterized as a "crime against humanity," comparable in scope to the November 1938 Kristallnacht in Germany, perpetrated by the Nazi authorities against Jewish civilians.

The Septemvriana satisfies the criteria of article 2 of the 1948 Convention on the Prevention and Punishment of the Crime of Genocide (UNCG) because the "intent to destroy in whole or in part" the Greek minority in Istanbul was demonstrably present, the pogrom having been orchestrated by the government of Turkish Prime Minister Adnan Menderes. Even if the number of deaths (estimated at thirty-seven) among members of the Greek community was relatively low, the result of the pogrom was the flight and emigration of the Greek minority of Istanbul, which once numbered some 100,000 and was subsequently reduced to a few thousand. The vast destruction of Greek property, businesses, and churches provides evidence of the Turkish authorities' intent to terrorize the Greeks in Istanbul into abandoning the territory, thus eliminating the Greek minority. This practice falls within the ambit of the crime of "ethnic cleansing," which the UN General Assembly and the International Criminal Tribunal for the former Yugoslavia have interpreted as constituting a form of genocide.

Turkey has been a party to the UNCG since 1950. Although it is not a party to the 1968 Convention on the Non-applicability of Statutory Limitations to War Crimes and Crimes against Humanity, modern international law imposes the principle of non-prescription to genocide and crimes against humanity. Accordingly, the obligation to punish the guilty and the responsibility of Turkey to make reparations to the victims and their survivors have not lapsed.

Seen in isolation, the Istanbul pogrom can be considered a grave crime under both Turkish domestic law and international law. In the historical context of a religiondriven eliminationist process accompanied by many pogroms before, during, and after World War I within the territories of the Ottoman Empire, including the destruction of the Greek communities of Pontos and Asia Minor and the atrocities against the Greeks of Smyrna in September 1922, the genocidal character of the Istanbul pogrom becomes apparent. It should be noted, however, that whereas the characterization of the Septemvriana as a form of genocide lends it greater emotional impact, the legal consequences are essentially the same whether the pogrom is classified under the rubric of genocide or as a crime against humanity.

\section{Historical Overview}

On 6-7 September 1955 violent riots (sometimes referred to as Septemvriana) occurred against the Greek minority living in Istanbul. The event was comparable in scope to

Alfred de Zayas, "The Istanbul Pogrom of 6-7 September 1955 in the Light of International Law." Genocide Studies and Prevention 2, 2 (August 2007): 137-154. (C) 2007 Genocide Studies and Prevention. doi: 10.3138/gsp/003 
the 1938 Kristallnacht $^{1}$ in Germany, perpetrated by the Nazi SS and SA against Jewish synagogues and property in November 1938. In the weeks leading up to the Istanbul pogrom, ${ }^{2}$ Turkish authorities had engaged in systematic incitement of public opinion against the Greek minority, partly in connection with the ongoing dispute over Cyprus. ${ }^{3}$ A student movement calling itself Cyprus Is Turkish was particularly virulent in creating anti-Greek propaganda. On 28 August 1955 the largest daily newspaper, Hürriyet, threatened that "if the Greeks dare touch our brethren, then there are plenty of Greeks in Istanbul to retaliate upon." ${ }^{4}$ At ten minutes past midnight on 6 September 1955, an explosion occurred in the courtyard of the Turkish Consulate in Thessaloniki, a building adjacent to the house where Kemal Atatürk was born. The press immediately blamed the Greeks and published photos of Atatürk's house that purported to show extensive damage. ${ }^{5}$ At the 1960/1961 Yassiada trial against Prime Minister Adnan Menderes and Foreign Minister Fatin Zorlu, it became known that the explosion had been carried out by Turkish agents under orders from the Turkish government. ${ }^{6}$

Beginning around 5:00 p.m., ${ }^{7}$ Turkish mobs devastated the Greek, Armenian, and Jewish districts of Istanbul, killing an estimated thirty-seven Greeks ${ }^{8}$ and destroying and looting their places of worship, ${ }^{9}$ homes, and businesses. The pogrom was not spontaneous but centrally organized: many of the rioters were recruited in Istanbul and in the provinces by the Demokrat Parti authorities and taken into Istanbul by train, in trucks, and by some 4,000 taxis with instructions on what to destroy and what was to be spared. ${ }^{10}$ They were given axes, crowbars, acetylene torches, petrol, dynamite, and large numbers of rocks in carts. Predictably, the riots got out of control, with the mobs shouting "Evvela mal, sonra can" ("First your property, then your life"). ${ }^{11}$ The Turkish militia and police who coordinated the pogrom refrained from protecting the lives and property of the Greek victims. ${ }^{12}$ Their function was, rather, to prevent Turkish property from being destroyed as well.

These events are best described in English by Speros Vryonis in his 2005 book The Mechanism of Catastrophe, which also draws on a vast range of Turkish sources, including the Yassiada trials, and on the substantive report published by Helsinki Watch (now Human Rights Watch) ${ }^{13}$ in 1992 on violations of the human and civil rights of the Greeks of Turkey. There is still no official Turkish government or police report on the violence of 6-7 September 1955.

Besides the deaths, thousands were injured; some 200 Greek women were raped, ${ }^{14}$ and there are reports that Greek boys were raped as well. ${ }^{15}$ Many Greek men, including at least one priest, were subjected to forced circumcision. The riots were accompanied by enormous material damage, ${ }^{16}$ estimated by Greek authorities at US $\$ 500$ million, including the burning of churches and the devastation of shops ${ }^{17}$ and private homes. ${ }^{18}$ As a result of the pogrom, the Greek minority eventually emigrated from Turkey. ${ }^{19}$

After the fall of the Menderes government in 1960, Menderes and other organizers of the pogrom were put on trial and convicted. The Yassiada trial of 1960/1961 provides abundant evidence as to the intent to terrorize and destroy the Greek minority of Istanbul. Menderes, Zorlu, and their minister of economics, Hasan Polatkan, were executed. ${ }^{20}$

\section{Norms}

Under customary international law, massacres such as occurred in Istanbul in September 1955 constitute international crimes. There are many norms of 
international law, international humanitarian law, and international human-rights law that are pertinent to an examination of the Istanbul pogrom. Under these norms, the pogrom, taken in isolation, involves a multiplicity of violations of international law. But it is in historical context that the Istanbul pogrom emerges as part of a genocidal program aimed at the destruction of the Greek presence in all territories under Turkish rule.

Massacres committed by the Ottoman authorities against the Armenians during World War I were labeled "crimes against humanity and civilization" by the British and the French governments as early as $1915 .{ }^{21}$ At the end of World War I, the victorious Allies agreed that the atrocities committed against the Christian minorities under Ottoman rule-including the Armenians; the Greeks of Pontos, Asia Minor, and Eastern Thrace; and the Assyrians-should be investigated and punished and that the material damage should be compensated. Relevant precedents are article 230 of the Treaty of Sèvres, ${ }^{22}$ which stipulated the obligation to punish, and art. 144, which stipulated the obligation to grant restitution and compensation. ${ }^{23}$

Although the Ottoman state signed the Treaty of Sèvres, formal ratification never followed, and the Allies did not follow through to ensure its implementation. ${ }^{24}$ Such failure can be attributed to the growing international political disarray following World War I, the rise of Soviet Russia, the withdrawal of the British military presence from Turkey, ${ }^{25}$ the isolationist policies of the United States ${ }^{26}$ the demise of the Young Turk regime, and the rise of Kemalism in Turkey. Nevertheless, the criminality of the massacres against Armenians, Greeks, and Assyrians had been acknowledged by the international community, even though no Turkish official was ever tried before an international tribunal and only a few were indicted, tried, and convicted by Turkish courts-martial.

The term "genocide" was coined by the Polish jurist Raphael Lemkin in 1944 in connection with the Nazi murder of the Jews. The London Agreement of 8 August 1945 laid down the indictment for the Nuremberg trials, including the offense of "crimes against humanity" under art. 6(c) of the Nuremberg Statute. ${ }^{27}$

The 1948 Convention on the Prevention and Punishment of the Crime of Genocide (UNCG) ${ }^{28}$ did not create the crime of genocide, but it formalized and codified the international prohibition of massacres. Article 1 of the UNCG stipulates that "genocide, whether committed in time of peace or in time of war, is a crime under international law"; art. 2 provides that

genocide means any of the following acts committed with intent to destroy, in whole or in part, a national, ethnical, racial or religious group, as such:

(a) killing members of the group;

(b) causing serious bodily or mental harm to members of the group;

(c) deliberately inflicting on the group conditions of life calculated to bring about its physical destruction in whole or in part

Turkey acceded to the convention on 31 July 1950, more than five years before the events of September 1955.

Of crucial importance here is the international rule of non-prescription, reflected in art. 1 of the UN Convention on the Non-applicability of Statutory Limitations to War Crimes and Crimes against Humanity, ${ }^{29}$ according to which the passage of time does not extinguish the obligation to prosecute in cases of genocide and crimes against humanity. As a consequence of this same principle, the passage of time does not extinguish the justiciability of claims to restitution. Moreover, there is an obligation 
erga omnes $^{30}$ not to recognize the material consequences of genocide and crimes against humanity.

International law has continued its normative development in this direction. For example, although the International Criminal Tribunal for the former Yugoslavia (ICTY) has no jurisdiction in connection with the Istanbul pogrom, it expands our understanding of the concept of genocide and its criminalization. Thus, art. 4 of the 1993 Statute of the ICTY defines the crime of genocide, and art. 5(g) lists rape as a "crime against humanity." 31

Similarly, art. 6 of the 1998 Rome Statute of the International Criminal Court (ICC) defines genocide in the terms of the UNCG; art. 7 defines "crimes against humanity" in terms more explicit than those in the Nuremberg Statute. ${ }^{32}$ However, pursuant to art. 11 of the statute, the ICC shall have no competence ratione temporis to examine events that occurred prior to the entry into force of the statute on 1 July 2002.

In the domain of "soft law," it is important to recall that in 1992 the UN General Assembly adopted Resolution 47/121, stipulating that the Yugoslav policy of "ethnic cleansing" was a "form of genocide"; 33 in 1995 the General Assembly adopted Resolution 50/192, which addresses the systematic practice of rape in the context of "ethnic cleansing" and reaffirms

that rape in the conduct of armed conflict constitutes a war crime and that under certain circumstances it constitutes a crime against humanity and an act of genocide as defined in the Convention on the Prevention and Punishment of the Crime of Genocide. $^{34}$

In the field of international human-rights law, Turkey has been a party to the International Covenant on Civil and Political Rights (ICCPR) since 15 September 2003. ${ }^{35}$ Article 6 protects the right to life; art. 20 prohibits incitement to racial hatred and incitement to violence; art. 26 prohibits discrimination; and art. 27 guarantees the rights of minorities. In November 2006 Turkey also ratified the Optional Protocol to ICCPR, but added a reservation precluding its retroactive application. In regional international law, Turkey signed the European Convention on Human Rights and Fundamental Freedoms on 4 November 1950 and ratified it on 18 May $1954 .{ }^{36}$ Turkey also ratified Protocol I on 22 June 1953. The European Convention protects the right to life, and its Protocol I protects the right to property. The 1955 pogrom should thus also be viewed from the perspective of international human-rights law.

\section{Case Law}

Bearing in mind that law is not mathematics, judges have to determine how the norms apply to a particular set of facts. While one judge may conclude that a pogrom constitutes genocide, another may conclude that it does not go over the threshold. But since a pogrom entails multiple violations of general principles of law and of human-rights law, the obligation to punish the guilty and to provide reparation to the victims is essentially the same.

The Nuremberg judgment of 1946 convicted the Nazis of crimes against humanity, including genocide. ${ }^{37}$ Massacres against a state's own citizens and permanent residents, such as the victims of the Kristallnacht of 9-10 November 1938, were also deemed to constitute a "crime against humanity." 38

The ICTY has applied the concept of "genocide" to individual massacres and determined, in the judgment against General Radislav Krstic ${ }^{39}$ that the massacre of Srebrenica constituted genocide. ${ }^{40}$ However, not every individual or political authority associated with the Srebrenica massacre has been charged with or 
convicted of genocide. The ICTY has also held that rape can in certain circumstances constitute the crime of genocide, ${ }^{41}$ and in its 2001 judgment against Kunarac, Kovac, and Vucovic, the ICTY also found that rape constitutes a "crime against humanity." 42

The principal architects of the Istanbul pogroms were tried, convicted, and punished under Turkish law in 1961. Former prime minister Menderes and a total of 592 other individuals were charged at the Yassiada trials in 1960/1961. The documentation and testimony emerging from this trial are sufficient to establish the "intent" of the Menderes government to "destroy in whole or in part" the Greek minority in Istanbul. ${ }^{43}$

\section{The Doctrine of State Responsibility for Wrongful Acts}

A general principle of international law stipulates that a state is responsible for injuries caused by its wrongful acts and must provide reparation for such injury. ${ }^{44}$ The Permanent Court of International Justice enunciated this principle in the Chorzow Factory Case as follows: "it is a principle of international law, and even a general conception of law, that any breach of an engagement involves an obligation to make reparation." 45

It should be stressed that the wrong in question is no mere violation of international law engaging interstate responsibility but the gravest criminal violation of international law, engaging, as the International Court of Justice (ICJ) has determined, international responsibility erga omnes - an obligation of the state toward the international community as a whole.

Thus, the international crime of genocide imposes obligations not only on the state that perpetrated the genocide but also on the entire international community: (a) not to recognize as legal a situation created by an international crime, (b) not to assist the author of an international crime in maintaining the illegal situation, and (c) to assist other states in the implementation of the aforementioned obligations. ${ }^{46}$ In a very real sense, the legal impact of the erga omnes nature of the crime of genocide goes far beyond the mere retroactivity of application of the UNCG: it imposes an affirmative obligation on the international community not to recognize an illegal situation resulting from genocide.

\section{Imprescriptibility of Genocide and Crimes against Humanity}

When, in 1968, the United Nations drafted the Convention on the Non-Applicability of Statutory Limitations to War Crimes and Crimes Against Humanity, it clearly and deliberately pronounced its retroactive application. Article 1 stipulates that

No statutory limitation shall apply to the following crimes, irrespective of the date of their commission... crimes against humanity, whether committed in time of war or in time of peace as they are defined in the charter of the International Military Tribunal, Nürnberg, of 8 August $1945 \ldots$ and the crime of genocide as defined in the 1948 Convention." 47

The principle of nullum crimen sine lege, nulla poena sine lege praevia (no crime without law, no penalty without previous law), laid out in paragraph 1 of art. 15 of the ICCPR, is conditioned as follows in para. 2:

Nothing in this article shall prejudice the trial and punishment of any person for any act or omission which, at the time when it was committed, was criminal according to the general principles of law recognized by the community of nations. 
Although Turkey is not a state party to the above-mentioned convention, international law is clear on the subject: there is no prescription on the prosecution of the crime of genocide, regardless of when the genocide occurred, and the obligation of the responsible state to make restitution or pay compensation for properties obtained by means of genocide does not lapse with time.

In its judgment of 6 October 1983 in the case of Klaus Barbie, the French Cour de Cassation rejected the objections of the defense and stated that the prohibition on statutory limitations for crimes against humanity is now part of customary international law. ${ }^{48}$ France also enacted a law on 26 December 1964 dealing with crimes against humanity as "imprescriptibles" by nature. ${ }^{49}$

Similarly, the Inter-American Court of Human Rights has ruled that "provisions on prescription... are inadmissible" when they "are intended to prevent the investigation and punishment of those responsible for serious human rights violations such as torture, extrajudicial, summary or arbitrary execution and forced disappearance," since they "violate non-derogable rights recognized by international human rights law." 50

\section{Imprescriptibility of the Right to Restitution and Compensation in Cases of Genocide and Crimes against Humanity}

Because of the continuing character of the crime of genocide in factual and legal terms, the remedy of restitution is not foreclosed by the passage of time. ${ }^{51}$ Thus the survivors of the Istanbul pogrom, like the survivors of the massacres against the Greeks of Pontos and Smyrna, have standing, both individually and collectively, to advance a claim for restitution. This has also been true for the Jewish survivors of the Holocaust, who have successfully claimed restitution against many states where their property was destroyed or confiscated. ${ }^{52}$ Whenever possible, restitutio in integrum (complete restitution, restoration to the previous condition) should be granted, so as to reestablish the situation that existed before the violation occurred. But where restitutio in integrum is not possible, compensation may be substituted as a remedy.

Restitution remains a continuing state responsibility also because of Turkey's current human-rights obligations under international treaty law, particularly the corpus of international human-rights law.

The UN Basic Principles and Guidelines on the Right to Reparation for Victims of Gross Violations of Human Rights and International Humanitarian Law provide in part that

Reparation may be claimed individually and where appropriate collectively, by the direct victims of violations of human rights and international humanitarian law, the immediate family, dependants or other persons or groups of persons closely connected with the direct victims.

Particularly important are principle 9:

Statutes of limitations shall not apply in respect of periods during which no effective remedies exist for violations of human rights or international humanitarian law. Civil claims relating to reparations for gross violations of human rights and international humanitarian law shall not be subject to statutes of limitations. 
and principle 12:

Restitution shall be provided to re-establish the situation that existed prior to the violations of human rights or international humanitarian law. Restitution requires, inter alia, ... return to one's place of residence and restoration of ... property ${ }^{53}$

Louis Joinet, member of the UN Sub-commission on Prevention of Discrimination and Protection of Minorities presented two reports containing comparable language:

Any human rights violation gives rise to a right to reparation on the part of the victim or his beneficiaries, implying a duty on the part of the State to make reparation and the possibility of seeking redress from the perpetrator. ${ }^{54}$

Although the ICC, established in July 2002, does not have jurisdiction to examine instances of genocide that occurred prior to the entry into force of the Rome Statute, it does reaffirm the international law obligation of providing reparation to victims. Article 75, para 1, of the Rome Statute stipulates that "The Court shall establish principles relating to reparations," which it defines as restitution, compensation, and rehabilitation.

This obligation under international law to make reparation for violations of rights is reaffirmed in General Assembly Resolution 60/147 of 16 December 2005. Pursuant to art. 11 of the principles enumerated in this resolution, the remedies for gross violations of human rights include the victim's right to “(a) equal and effective access to justice; (b) adequate, effective and prompt reparation for harm suffered; c) access to relevant information concerning violations and reparation mechanisms." Pursuant to art. 6, "statutes of limitations shall not apply to gross violations of international human rights law and serious violations of international humanitarian law which constitute crimes under international law."55

In the context of reparation for gross violations of human rights, two other general principles are relevant: the principle ex injuria jus non oritur (no right arises from a wrong), that no state should be allowed to profit from its own violations of law; and the principle of "unjust enrichment." It is a general principle of law that the criminal cannot keep the fruits of the crime. ${ }^{57}$

In denying the applicability of statutes of limitation to restitution claims by survivors of the Holocaust, Irwin Cotler argues,

The paradigm here is not that of restitution in a domestic civil action involving principles of civil and property law, or restitution in an international context involving state responsibility in matters of appropriation of property of aliens; rather, the paradigm-if there can be such a paradigm in so abhorrent a crime-is that of restitution for Nuremberg crimes, which is something dramatically different in precedent and principles.... Nuremberg crimes are imprescribable $[s i c],{ }^{58}$ for Nuremberg law-or international laws anchored in Nuremberg Principles-does not recognize the applicability of statutes of limitations, as set forth in the Convention on the Non-Applicability of Statutory Limitations to War Crimes and Crimes Against Humanity. ${ }^{59}$

\section{The Doctrine of Non-recognition}

Hersch Lauterpacht points out that the doctrine of non-recognition is based on the principle of ex injuria jus non oritur:

This construction of non-recognition is based on the view that acts contrary to international law are invalid and cannot become a source of legal rights 
for the wrongdoer. That view applies to international law one of "the general principles of law recognized by civilized nations." The principle ex injuria jus non oritur is one of the fundamental maxims of jurisprudence. An illegality cannot, as a rule, become a source of legal right to the wrongdoer. ${ }^{60}$

Similarly, the "Friendly Relations" resolution of the General Assembly stipulates that "No territorial acquisition resulting from the threat or use of force shall be recognized as legal." 61 In cases of "ethnic cleansing," the rights of the entire international community have been affected, and every state is obliged to refrain from giving recognition or effect to the consequences of the crime. For instance, art. 10 of the Draft Declaration on Population Transfer and the Implantation of Settlers concerning the illegality of population transfers provides in part that "Where acts or omissions prohibited in the present Declaration are committed, the international community as a whole and individual States, are under an obligation ... not to recognize as legal the situation created by such acts." 62

On 9 July 2004 the ICJ issued an advisory opinion on the legality of Israel's construction of a security wall, concluding that states had an obligation of non-recognition:

Given the character and the importance of the rights and obligations involved, the Court is of the view that all States are under an obligation not to recognize the illegal situation resulting from the construction of the wall in the Occupied Palestinian Territory, including in and around East Jerusalem. They are also under an obligation not to render aid or assistance in maintaining the situation created by such construction. ${ }^{63}$

\section{Bringing the Istanbul Pogrom before an International Tribunal}

Although Turkey had ratified the European Convention on Human Rights, and was bound by its provisions, when the Istanbul pogrom took place, the individual complaints procedure before the European Court under art. 34 of the convention requires that petitions be submitted within six months after the exhaustion of domestic remedies. Bearing in mind that the events occurred fifty-two years ago, the court would now declare the petition inadmissible ratione temporis pursuant to art. 35 , para. 1 , of the convention.

Interstate complaints, however, may be lodged under art. 33 of the European Convention, and any state party to the convention could submit such an interstate application. The friendly settlement procedure could lead to appropriate lump-sum reimbursements to the victims and their survivors.

Turkey ratified the ICCPR in 2003 and acceded to the Optional Protocol (OP) thereto in November 2006. By virtue of the OP, the UN Human Rights Committee (HRC) is thus competent to examine individual complaints against Turkey. However, Turkey has made a reservation to the OP restricting its application to facts and events occurring prior to the entry into force of the OP for Turkey, thus excluding any examination of the violations of the right to life (art. 6) and cruel and degrading treatment (art. 7) accompanying the Istanbul pogrom. Turkey has also not given the declaration, under art. 41 of the ICCPR, that would give the HRC competence to entertain interstate complaints. Thus, the only avenue of redress would be through the examination of Turkey's periodic reports to the HRC under art. 40 of the ICCPR. Although this is not a complaints procedure, the HRC would take cognizance of the failure of the state party to give appropriate restitution and compensation to the victims of the Istanbul pogrom. 
Pursuant to art. 34 of the Statute of the ICJ, only states may be parties in cases before the court. Thus, individuals or groups lack standing before the ICJ. Although the court can examine ad hoc cases submitted by states parties, it cannot do so if one of the parties does not accept the ICJ's competence, and Turkey has let its declaration under art. 36(2), recognizing as compulsory ipso facto the jurisdiction of the court, expire.

A contentious case concerning the 1948 UNCG, however, could be entertained notwithstanding the absence of a declaration by Turkey under art. 36, para. 2, of the statute. Indeed, pursuant to art. 36 , para. 1, this would be possible, because Turkey is a state party to the UNCG, which stipulates in article 9 that

Disputes between the Contracting Parties relating to the interpretation, application or fulfillment of the present convention, including those relating to the responsibility of a State for genocide or for any other acts enumerated in article III, shall be submitted to the International Court of Justice at the request to any of the parties to the dispute.

Greece has also been a party to the UNCG since 8 December 1954, that is, since before the Istanbul pogrom took place. Accordingly, it would be possible for Greece (or for any other state party to the UNCG) to argue before the ICJ that the Istanbul pogrom constituted "genocide" within the meaning of the convention and that Turkey is obliged to ensure appropriate compensation to the victims and their survivors.

Greece (or any state party to the UNCG) could also invoke art. 8 of the UNCG, which provides that any contracting party may call upon the competent organs of the United Nations to take such action as they consider appropriate for the "suppression" of genocide. "Suppression" must mean more than just retributive justice. In order to suppress the crime, it is necessary to suppress, as far as possible, its consequences. This entails, besides punishing the guilty, providing restitution and compensation to the surviving generations.

Another possibility would be to have the UN General Assembly, pursuant to art. 96 of the UN Charter, refer the matter to the ICJ for an advisory opinion, as was done in the cases relating to South Africa's presence in Namibia in 1970 and of Israel's security wall in 2003. ${ }^{64}$ The ICJ could, pursuant to art. 65 of the ICJ Statute, consider the question of whether the consistent pattern of Turkey's anti-Greek measures constituted "crimes against humanity" or "genocide," and could then fix the level of compensation and restitution required.

Admittedly, the criminal law aspects of the UNCG are of lesser relevance in the context of the Istanbul pogrom, since most of the principal perpetrators of the Septemuriana are no longer alive or are too old to be prosecuted. On the other hand, the Greek properties that were destroyed, for which their owners were not sufficiently compensated, give rise to legitimate claims against the Turkish state. In this context, it is worth noting the important restitution of many churches and monasteries in the former Soviet republics, including Armenia-restitution effected in the 1990s for confiscations that had occurred some seventy years earlier, following the Bolshevik revolution. ${ }^{65}$ Based on this precedent, compensation for the damage caused to Greek churches and monasteries would appear to be not only morally mandated but also implementable in practice.

A determination by the ICJ that Istanbul Program constituted a form of genocide would facilitate the settlement of claims for restitution, including the identification of cultural and other properties destroyed, such as churches, monasteries, and other assets of historic and cultural significance to the Greek communities of Turkey. 


\section{Conclusion}

The Istanbul pogrom was a phase in the Ottoman/Turkish policy of eliminating Greek communities from their 3,000-year-old homelands in Asia Minor, Thrace, the Aegean, and Constantinople itself. Seen in the context of a centuries-old process of discrimination, massacres, and expulsion, it can be classified as a form of genocide. ${ }^{66}$ At the same time, the Istanbul pogrom also falls within the definition of crimes against humanity in both the Nuremberg Statute and in the Rome Statute of the ICC. Because these crimes are not subject to statutes of limitations, Turkey still has important international legal obligations to meet.

Turkey aspires to membership in the European Union, which is a community not only of commercial interests but also of certain fundamental moral values. By acknowledging its responsibility for the Istanbul pogrom, for other massacres, and for the consistent pattern of religious intolerance, ${ }^{67}$ Turkey would make its commitment to human rights, including the right to truth, ${ }^{68}$ more credible. It is incompatible with this commitment to human rights that those responsible for the Istanbul pogrom have been rehabilitated, and schools and airports named after them. This state of affairs poses a serious challenge to the European community. ${ }^{69}$

A modern, democratic Turkey, bound by the European Convention on Human Rights and the International Covenant on Civil and Political Rights, must still address these issues.

\section{Notes}

1. Rita Thalmann, "Kristallnacht," in Encyclopedia of Genocide and Crimes against Humanity, ed. Dinah Shelton, vol. 2, 626-28 (Woodbridge, CT: Macmillan Reference, 2004). No less than 257 synagogues and some 7,500 shops were destroyed or damaged. The number of Jews killed in the rioting is unknown, estimates between thirty-six and ninety-one being frequently given.

2. "Pogrom" is a term commonly used to refer to anti-Jewish riots in Russia, particularly those that took place in 1881-82, 1903, and 1905 in Odessa, Kiev, and other cities and villages of the Russian Empire. One of the most infamous massacres was the Kishinev Pogrom of 6-7 April 1903, in which forty-seven Jewish persons lost their lives and mob violence caused considerable property damage in Chisinau, the capital of Bessarabia (now the Republic of Moldova). Parallels can be drawn to the events of 6-7 September 1955 in Istanbul: the number of victims (Jewish or Greek) was also relatively low, and the involvement of the authorities (Russian or Turkish) in the preparation of the riots and their failure to repress them raise the same issues of state responsibility. Both the pogroms against the Jewish population of Russia and the September 1955 massacres in Istanbul led to mass emigration of the targeted populations. See John Klier, "Pogroms, Pre-Soviet Russia," in Encyclopedia of Genocide and Crimes against Humanity, ed. Dinah Shelton, vol. 2, 812-15 (Woodbridge, CT: Macmillan Reference, 2004). Of similar magnitude was the pogrom on 4 July 1946 in Kielce, Poland, during which some forty-one Jewish Holocaust survivors were massacred.

3. The issue of Cyprus was a convenient pretext to incite the populace to violence against the Greeks. The Ottoman and Turkish governments had a long-established policy of discrimination against the Greek minority, which manifested itself not only in riots but also in anti-Greek laws (reminiscent of the Nazis' Nuremberg laws) that excluded Greeks from certain professions; the special Wealth Tax of 1942; the recruitment of Greeks and Armenians into special work battalions during World War II; and so on. Speros Vryonis, The Mechanism of Catastrophe (New York: Greekworks, 2005), 32-48. 
4. Alexis Alexandris, The Greek Minority of Istanbul and Greek-Turkish Relations 1918-1974 (1983; reprint, Athens: Centre for Asia Minor Studies, 1992), 256.

5. On 6 September Istanbul papers carried headlines such as "Greek terrorists defile Atatürk's birthplace." On 7 September 1955 Turkish State Radio carried a broadcast that stated in part, "The criminal attack undertaken against the house of our dear Atatürk and our consulate in Salonika, added to the deep emotion created over a period of months in public opinion by the developments in connection with the question of Cyprus ... has provoked demonstrations on the part of large masses which have continued... in Istanbul until late last night." Quoted in Vryonis, Mechanism of Catastrophe, 118, 193.

6. The agent provocateur in Thessaloniki, the student Oktay Engin, was acquitted at the Yassiada trial, and lived to occupy high positions in the Turkish state after the Istanbul pogrom. Ibid., 530.

7. According to various sources, the riots began in various parts of Istanbul and Izmir between 4:00 and 8:00 p.m. Vryonis provides a table according to which the pogrom struck Yedikule, Samatya, Beyoğlu, Siraselviler, and Yeşilköy at 7:00 p.m.; Edirnekapi at 8:30 p.m.; Kalyoncu Kulluk at 9:00 p.m.; Aksaray at 11:00 p.m.; Kurtuluş "when night fell"; and Kuzguncuk "after midnight." Ibid., 103-4.

8. Vryonis, Mechanism of Catastrophe, 581-82 (Appendix B, "List of the Dead in the Pogrom"). Thirty victims were identified, three unidentified bodies were dug out of destroyed shops, and three burned bodies were found in a sack in Beşiktaş. Leonidas Koumakes, The Miracle: A True Story (Athens: n.p., 1982), 54-55, speaks of the death of more than twenty people. Lois Whitman lists fifteen deaths in Denying Human Rights and Ethnic Identity: The Greeks of Turkey (New York: Helsinki Watch/Human Rights Watch, 1992), 50.

9. The Greek Patriarchate in Istanbul, in dispatch 139 (Istanbul to Washington, DC), reported that sixty-one churches, four monasteries, two cemeteries, and thirty-six Greek schools had been devastated. Vryonis, Mechanism of Catastrophe, 268. Between chapters 3 and 4 of the same book appear, inter alia, photos of the destroyed churches of Saint Constantine and Helen, Saint George Kyparissas, Saint Menat in Samatya, and Saint Theodoroi in Langa; the Church of the Metamorphonis; and the Panagia in Belgratkapi, as well as cemeteries and the open and desecrated tombs of the ecumenical patriarachs. Ibid., facing p. 288. These photographs of the destructions were taken by D. Kaloumenos and smuggled out of Turkey by the journalist G. Karagiorgas. The Athens newspaper Ethnos published some early photos on 12 September 1955; Kaloumenos published more photos in Greece after his expulsion from Turkey in 1957. See D. Kaloumenos, The Crucifixion of Christianity, 4th ed. (Athens: n.p., 2001) [in Greek]. According to Whitman, The Greeks of Turkey, 8, "More than 4,000 Greek shops were sacked and plundered; 38 Churches were burned down and 35 more churches vandalized; two monasteries and the main Greek Orthodox cemeteries were vandalized and, in some cases, destroyed; more than 2,000 Greek homes were vandalized and robbed, and 52 Greek schools were stripped of their furniture, books and equipment."

10. Targets were marked with paint, and the attackers had lists, as was the case on Kristallnacht.

11. Vryonis, Mechanism of Catastrophe, 211.

12. The American consul general telegraphed the US State Department to report that "the destruction was completely out of hand with no evidence of police or military attempts to control it. I personally witnessed the looting of many shops while the police stood idly by or cheered on the mob." Whitman, The Greeks of Turkey, 7.

13. Human Rights Watch is a New York-based non-governmental organization, founded in 1978 as Helsinki Watch.

14. Vryonis, Mechanism of Catastrophe, 222. The estimates go as high as 2,000 rapes. One of the most frequently mentioned cases of rape involved the Working Girls' Hostel on the island of Büyükada (Prinkipo). List of victims were established by the Ecumenical Patriarchate and by the Greek consul general. 
15. Ibid., 224.

16. The US Consulate in Istanbul sent a dispatch to the State Department on 27 September 1955 which reads in part, "A survey of the damage inflicted on public establishments of the Greek Community of Istanbul during the rioting on the night of September 6-7 shows that the destruction caused has been extremely widespread. In fact, only a very small percentage of community property appears to have escaped molestation. Although there are as yet no figures available assessing the damage sustained, the number of establishments attacked and the nature of the destruction caused ... convey a clear picture of the scope of the devastation. In most cases the assault on these establishments involved a thorough wrecking of installations, furniture, equipment, desecration of holy shrines and relics, and looting. In certain instances serious damage was inflicted on the buildings themselves by fire." Whitman, The Greeks of Turkey, 7.

17. Vryonis, Mechanism of Catastrophe, 248. According to the Istanbul police, 2,572 Greek, 741 Armenian, and 523 Jewish businesses were destroyed. Vryonis provides a list of 329 destroyed businesses on pages 251-59; in a separate table he lists a survey according to which 1,100 shops and 600 homes owned by Greek nationals, 3,000 shops owned by Turkish citizens of Green ethnic origin (the Greek minority), and 1,500 homes were destroyed. Ibid., 270.

18. Ibid., 220.

19. Whitman, The Greeks of Turkey, 6-8: "After the population exchange [of 1923] there were between 100,000 and 110,000 Greeks in Turkey, most of them in Istanbul and a smaller number on the islands of Imbros and Tenedos. Today, the Greek community does not appear to number more than 2,500-about 2,000 in Istanbul and about 480 on the two islands.” In his 2000 report to the UN General Assembly, Special Rapporteur Abdelfattah Amor quotes statistics of the Turkish Ministry of Foreign Affairs, according to which there were between 3,500 and 4,000 Orthodox Greeks in all of Turkey at that time. Abdelfattah Amor, Report on the Elimination of All Forms of Religious Intolerance, 11 August 2000, UN Doc. A/55/280/Add. 1, 3 [Amor Report].

20. Menderes was convicted on many counts, and his death sentence was based primarily on other offences, including the "abuse of discretionary funds." Given the gravity of the crimes committed in the Istanbul pogrom, it is disturbing to note that the young generation of Turks know little or nothing about it and that subsequent governments have honored the memory of Menderes, Zorlu, and Polatkan. Both a university in Aydin and the international airport in İzmir are named after Menderes; two high schools, Istanbul Bahçelievler Adnan Menderes Anadolu Lisesi and Aydın Adnan Menderes Anadolu Lisesi, also bear his name.

21. Alfred de Zayas, The Genocide against the Armenians 1915-1923 and the Relevance of the 1948 Genocide Convention (Brussels: European Armenian Federation for Justice and Democracy, 2005), 3. See also Egon Schwelb, "Crimes against Humanity," British Yearbook of International Law 23 (1946): 178-226, 181; Jean-Baptiste Racine, Le Génocide des Arméniens. Origine et permanence du crime contre l'humanité (Paris: Dalloz-Sirey, 2006); Reymond Kevorkian, Le Génocide des Arméniens (Paris: Éditions Odile Jacob, 2006).

22. Pursuant to art. 230 of the Treaty of Sèvres, "The Turkish Government undertakes to hand over to the Allied Powers the persons whose surrender may be required by the latter as being responsible for the massacres committed during the continuance of the state of war on territory which formed part of the Turkish Empire on the 1st August 1914. The Allied Powers reserve to themselves the right to designate the Tribunal which shall try the persons so accused and the Turkish Government undertakes to recognize such Tribunal." American Journal of International Law 15, Supplement: Official Documents (1921), 235. Those officers of the Ottoman state who had been imprisoned in Malta and should have been tried for crimes against humanity were granted an amnesty by virtue of the Treaty of Lausanne of 1923. See also William A. Schabas, Genocide in International Law (Cambridge: Cambridge University Press, 2000), 20-22. 
23. Art. 144 of the Treaty of Sèvres stipulated that "The Turkish Government recognizes the injustice of the law of 1915 relating to Abandoned Properties (Emval-I-Metroukeh), and of the supplementary provisions thereof, and declares them to be null and void, in the past as in the future. The Turkish Government solemnly undertakes to facilitate to the greatest possible extent the return to their homes and re-establishment in their businesses of the Turkish subjects of non-Turkish race who have been forcibly driven from their homes by fear of massacre or any other form of pressure since January 1, 1914." It recognizes that any immovable or movable property of the said Turkish subjects or of the communities to which they belong, which can be recovered, must be restored to them as soon as possible, in whatever hands it may be found... The Turkish Government agrees that arbitral commissions shall be appointed by the Council of the League of Nations wherever found necessary... These arbitral commissions shall hear all claims covered by this Article and decide them by summary procedure." American Journal of International Law 15, Supplement: Official Documents (1921).

24. André Mandelstam, La Societé des nations et les puissances devant le Problème armenien, 2nd ed. (Paris: Sirey, 1970).

25. Paul Helmreich, From Paris to Sèvres (Columbus: Ohio State University Press, 1974), 131-33.

26. Although US diplomats had condemned the Armenian Genocide as early as 1915, the US government did not take any action to redress the injustices after the war. It is worth remembering that US Ambassador Henry Morgenthau, Sr., had called the massacres "race murder" and that on 10 July 1915 he had cabled Washington with the following description of the Ottoman policy: "Persecution of Armenians assuming unprecedented proportions. Reports from widely scattered districts indicate systematic attempt to uproot peaceful Armenian populations and through arbitrary arrests, terrible tortures, whole-sale expulsions and deportations from one end of the empire to the other accompanied by frequent instances of rape, pillage, and murder, turning into massacre, to bring destruction and destitution on them. These measures are not in response to popular or fanatical demand but are purely arbitrary and directed from Constantinople in the name of military necessity, often in districts where no military operations are likely to take place."

Samantha Power, A Problem from Hell: America and the Age of Genocide (New York: Basic Books, 2002), 6.

27. Charter of the Nürnberg International Military Tribunal, 8 August 1945, http:// www.derechos.org/nizkor/nuremberg/ncharter.html (accessed 29 May 2007).

28. Convention on the Prevention and Punishment of the Crime of Genocide, 9 December 1948, 78 U.N.T.S. 277, http://www.unhchr.ch/html/menu3/b/p_genoci.htm (accessed 16 May 2007). The UNCG entered into force on 12 January 1951, in accordance with art. 13; there were 140 states parties as of January 2006.

29. Convention on the Non-applicability of Statutory Limitations to War Crimes and Crimes against Humanity, 26 November 1968, 754 U.N.T.S. 73, http://www.unhchr.ch/html/ menu3/b/p_limit.htm (accessed 16 May 2007) [Convention on Statutory Limitations]. This convention entered into force on 11 November 1970. Black's Law Dictionary defines "prescription" as the "effect of the lapse of time in creating and destroying rights." Black's Law Dictionary, 7th ed. (St. Paul, MN: West Publishing, 1999), 1201.

30. When a state breaches an obligation erga omnes, it injures every other state. Thus, every state is concerned and has standing to raise a claim for redress. Certain obligations apply to the entire community of states: for instance, the obligation to refrain from committing jus cogens crimes such as aggression, torture, and genocide. See J.A. Frowein, "Obligations erga omnes" in Encyclopedia of Public International Law, ed. R. Bernhardt, vol. 3, 757-59 (Amsterdam: North Holland, 1997).

31. Statute of the International Tribunal for the Prosecution of Persons Responsible for Serious Violations of International Humanitarian Law Committed in the Territory of the Former Yugoslavia since 1991, UN Doc. S/25704, 36, annex (1993), UN Doc. S/25704/Add.1 (1993), 
adopted by Security Council Resolution 827 (25 May 1993), UN Doc. S/RES/827. Compare art. 6(c) of the 1945 Nuremberg Statute.

32. Under customary international law, as codified in the Rome Statute, "crimes against humanity" is defined as "any of the following acts when committed as part of a widespread or systematic attack directed against any civilian population, with knowledge of the attack: (a) Murder; (b) Extermination; (c) Enslavement; (d) Deportation or forcible transfer of population; (e) Imprisonment or other severe deprivation of physical liberty in violation of fundamental rules of international law; (f) Torture; (g) Rape, sexual slavery, enforced prostitution, forced pregnancy, enforced sterilization, or any other form of sexual violence of comparable gravity; (h) Persecution against any identifiable group or collectivity on political, racial, national, ethnic, cultural, religious, gender as defined in paragraph 3 , or other grounds that are universally recognized as impermissible under international law, in connection with any act referred to in this paragraph or any crime within the jurisdiction of the Court; (i) Enforced disappearance of persons; (j) The crime of apartheid; (k) Other inhumane acts of a similar character intentionally causing great suffering, or serious injury to body or to mental or physical health." Rome Statute of the International Criminal Court, U.N. Doc. A/CONF.183/9 (17 July 1998), art. 7(1).

33. The Situation in Bosnia and Herzegovina, UN General Assembly Resolution 47/121, UN Doc. A/RES/47/121 (18 December 1992). The resolution was adopted by a recorded vote of 102 in favor, 0 against, and 57 abstentions.

34. Rape and Abuse of Women in the Areas of Armed Conflict in the former Yugoslavia, UN General Assembly Resolution 50/192, UN Doc. A/RES/50/192 (22 December 1995).

35. International Covenant on Civil and Political Rights, General Assembly Resolution 2200A(XXI), UN Doc. A/6316 (16 December 1966).

36. European Convention on Human Rights and Fundamental Freedoms, 4 November 1950, 213 U.N.T.S. 221, http://www.pfc.org.uk/node/328 (accessed 19 May 2007).

37. By Resolution 95(I) of 1946, the General Assembly "affirm[ed] the principles of international law recognized by the Charter of the Nürnberg Tribunal and the judgment of the Tribunal." Affirmation of the Principles of International Law Recognized by the Charter of the Nürnberg Tribunal, UN General Assembly Resolution 95(1), UN Doc. A/64/ Add.1 (11 December 1946). In Resolution 96(I), it confirmed "that genocide is a crime in international law, which the civilized world condemns, and for the commission of which principals and accomplices-whether private individuals, public officials or statesmen, and whether the crime is committed on religious, racial, political or any other grounds-are punishable." The Crime of Genocide, UN General Assembly Resolution 96(I), UN Doc. A/64/ Add.1 (11 December 1946).

38. There are many analogies to be drawn between the Kristallnacht of 1938 and the Istanbul pogrom of 1955 . Both were driven by a governmental intention to terrorize the targeted group so that they would leave. Both made an effort to restrict the number of persons killed, so as to avoid unnecessary international or diplomatic outrage. Both should be seen in the larger historical context. But while the Kristallnacht marked the beginning of the Holocaust, the Istanbul pogrom can be seen as one of the last phases in the "ethnic cleansing" of the Greeks from territories under Muslim-Turkish jurisdiction. International Military Tribunal, Trial of the Major War Criminals, vol. 1 (Nuremberg), 248, 271.

39. On 2 August 2001, General Krstić was the first person to be convicted of genocide by the ICTY. ICTY Trial Chamber, "Radislav Krstic Becomes the First Person to Be Convicted of Genocide at the ICTY and Is Sentenced to 46 Years Imprisonment" (press release, 2 August 2001, The Hague), http://www.un.org/icty/pressreal/p609-e.htm (accessed 17 May 2007).

40. Trial Chamber I of the ICTY ruled that the events at Srebrenica in July 1995 constituted "genocide." The actual number of persons killed in Srebrenica, however, is unknown. Of the 7,000 missing Muslims, 2,028 bodies were actually exhumed from mass graves, and the Trial Chamber noted that a number of these had died in combat. Prosecutor $v$. Krstić, Judgment, ICTY-98-33 (2 August 2001), para. 80.

41. See Prosecutor v. Akayesu, Judgment, ICTR-96-4-T (2 September 1998). 
42. Prosecutor v. Kunarac, Kovac, and Vukovic, Judgment, ICTY-96-23-T \& ICTY-96-23/1-T (22 February 2001), http://www.un.org/icty/foca/trialc2/judgement/index.htm (accessed 17 May 2007). See also Prosecutor v. Furundzija, Judgment, ICTY-95-17/1-T (10 December 1998); Prosecutor v. Delalic, Mucic, Delic, and Landzo, Judgment, ICTY-96-21-T (20 February 2001) [Celebici Trial Judgment]. See also "ICTY Prosecutor, Carla Del Ponte, Releases Background Paper on Sexual Violence Investigation and Prosecution" (press release, 8 December 1999, The Hague).

43. See Vryonis, Mechanism of Catastrophe, 43.

44. Malcolm Shaw, International Law, 5th ed. (Cambridge: Grotius Publications, 2003), 481: "A breach of an international obligation gives rise to a requirement for reparation"; Wladyslaw Czaplinski, "State Succession and State Responsibility," Canadian Yearbook of International Law 28 (1990): 339-59, 339: "State responsibility is a legal relationship created through the violation of an international legal obligation by a State; that violation gives rise to the duty to compensate for any resulting damage, one of the oldest principles of international law and universally recognized in international practice." See also Karl Zemanek, "Responsibility of States: General Principles," in Encyclopaedia of Public International Law, ed. R. Bernhardt, vol. 4, 219-29 (Amsterdam: North Holland, 2000); Mohammed Bedjaoui, "Responsibility of States: Fault and Strict Liability," in Encyclopaedia of Public International Law, ed. R. Bernhardt, vol. 4, 212-16 (Amsterdam: North Holland, 2000); Irwin Cotler, "Confiscated Jewish Property: The Holocaust, Thefticide and Restitution: A Legal Perspective," Cardozo Law Review 20 (1998): 601-24, 610.

45. Chorzow Factory Case (Germany v. Poland), 1928 P.C.I.J. (ser. A), No. 17, 29. See Ignaz Seidl-Hohenveldern, "German Interests in Polish Upper Silesia Cases," in Encyclopaedia of Public International Law, vol. 2, ed. R. Bernhardt, 550-53 (Amsterdam: North Holland, 1995).

46. Zemanek, "Responsibility of States," 226.

47. Convention on Statutory Limitations, art. 1 (emphasis added).

48. Fédération nationale des deportés et internés et patriots et al. v. Barbie, 78 I.L.R. 125, 135.

49. Nouveau Code penal de 1994, arts. 211-1-213-5. See Jacques Francillon, "Aspects juridiques des crimes contre l'humanité," in L'actualité du Génocide des Arméniens. Actes du colloque organisé par le Comité de défense de la cause arménienne à Paris-Sorbonne les 16, 17 et 18 avril 1998, ed. Hrayr Henry Ayvazian, Hrair Heratchian, Hélène Kosseyan, Bernard Legras, and Claire Mouradian, 397-404 (Creteil, France: Edipol, 1999), 398.

50. Barrios Altos Case, Judgment, Ser. C, No. 75, I.A.C.H.R. 5 (14 March 2001), 41; see also footnote reference 31. See Question of the Punishment of War Criminals and of Persons Who Have Committed Crimes against Humanity, UN General Assembly Resolution 2338(XXII) (18 December 1967), UN General Assembly Resolution 2583 (XXIV) (15 December 1969), UN General Assembly Resolution 2712 (XXV) (14 December 1970), UN General Assembly Resolution 2840 (XXVI) (18 December 1971); Principles of International Cooperation in the Detection, Arrest, Extradition and Punishment of Persons Guilty of War Crimes and Crimes Against Humanity, UN General Assembly Resolution 3020 (XXVII) (18 December 1972), UN General Assembly Resolution 3074 (XXVIII) (3 December 1973); etc.

51. A leading international law expert in Europe, the late Felix Ermacora, member of the UN Human Rights Committee, member of the European Commission on Human Rights, and Special Rapporteur of the UN Commission on Human Rights for Afghanistan and Chile, maintained this view. In a legal opinion on the continuing obligation to grant restitution to the expelled Germans from Czechoslovakia, some 250,000 of whom perished in the course of ethnic cleansing in 1945-1946, Ermacora wrote that because the confiscation was part of a genocidal process, no statute of limitations can apply to restitution claims. Felix Ermacora, Die Sudetendeutschen Fragen (Munich: Langen Müller, 1992), 178. 
52. Cotler, "Confiscated Jewish Property," 609; Sabine Thomsen, "Restitution," in Encyclopaedia of Public International Law, ed. R. Bernhardt, vol. 4, 229-32

(Amsterdam: North Holland, 2000); Irwin Cotler, "Nuremberg 50 Years Later: The Restitution of Jewish Property and Norwegian Justice," Nordic Journal of International Law 3 (1998): 275-87.

53. UN Commission on Human Rights, Question of the Human Rights of All Persons Subjected to Any Form of Detention or Imprisonment: Report of the Secretary-General, UN Doc. E/CN.4/Sub.2/1997/104 (26 June 1997). Compare Theo van Boven, Study Concerning the Right to Restitution, Compensation and Rehabilitation for Victims of Gross Violations of Human Rights and Fundamental Freedom: Final Report, UN Doc. E/CN.4/Sub.2/1993/8 (2 July 1993), s. IX; and Theo van Boven, The Administration of Justice and the Human Rights of Detainees: Revised Set of Basic Principles and Guidelines on the Right to Reparation for Victims of Gross Violations of Human Rights and Humanitarian Law, UN Doc. E/CN.4/Sub.2/1996/17 (24 May 1996).

54. Louis Joinet, Question of the Impunity of Perpetrators of Human Rights Violations (Civil and Political): Final Report, UN Doc. E/CN.4/Sub.2/1997/20 (26 June 1997), principle 36; Louis Joinet, The Administration of Justice and the Human Rights of Detainees:

Question of the Impunity of Perpetrators of Human Rights Violations (Civil and Political): Revised Final Report, UN Doc. E/CN.4/Sub.2/1997/20/Rev.1 (2 October 1997), principle 33.

55. Basic Principles and Guidelines on the Right to a Remedy and Reparation for Victims of Gross Violations of International Human Rights Law and Serious Violations of

International Humanitarian Law, UN General Assembly Resolution 60/147, UN Doc. A/RES/60/147 (21 March 2006), art. 11, art. 6.

56. Peter D. Maddaugh and John D. McCamus, Law of Restitution (Aurora, ON: Canada Law Book, 1990), 484-93. Even in the Old Testament we find an admonition against unjust enrichment: "Thus saith the Lord, Hast thou killed, and also taken possession?" 1 Kings 21:19 (King James Version). The story is that Naboth, a man from Jezreel, had a vineyard on the outskirts of the city near King Ahab's palace. The King coveted the land, because it was convenient to his palace, but Naboth did not want to sell, because the vineyard had been in his family for generations. Jezebel, Ahab's wife, persuaded Ahab to have Naboth falsely accused of blasphemy and stoned to death. When King Ahab went to take possession of the vineyard, however, the prophet Elijah admonished him: "Isn't killing Naboth bad enough? Must you rob him, too? Because you have done this, dogs shall lick your blood outside the city just as they licked the blood of Naboth!" 1 Kings 21:19, The Living Bible (Wheaton, IL: Tyndale House, 1971).

57. W.M. McGovern, "Homicide and Succession to Property," Michigan Law Review 68 (1969): 65-110. There is ample case law stating that "it is against public policy for a person who is guilty of feloniously killing another to take any benefit in that other person's estate." Re Johnson (1950), 2 D.L.R. 69, 75-76, 1 W.W.R. 263.

58. I.e., imprescriptible.

59. Cotler, "Confiscated Jewish Property," 621.

60. Hersch Lauterpacht, Recognition in International Law (Cambridge: Cambridge University Press, 1947), 420.

61. Declaration on Principles of International Law Concerning Friendly Relations and Cooperation among States in Accordance with the Charter of the United Nations, UN General Assembly Resolution 2625(XXV), UN Doc. A/RES/8082 (24 October 1970). See also the Report of the United Nations International Law Commission, 53rd session 2001, commentary to Article 41 of the Draft Report on Responsibility of States, GAOR, 56th Session, Supp. No. 10 (A/56/10), 2001, 289-90, para. 9. See also arts. 26 and 20 of the ILC Articles on State Responsibility.

62. Freedom of Movement: Human Rights and Population Transfer: Final Report of the Special Rapporteur, Mr. Al-Khasawneh, UN Doc. E/CN.4/Sub.2/1997/23, Annex II, art. 10. 
63. ICJ, Legal Consequences of the Construction of a Wall in the Occupied Palestinian Territory (advisory opinion), 9 July 2004, http://www.icj-cij.org/docket/files/131/1671.pdf (accessed 17 May 2007), para. 159.

64. ICJ, Legal Consequences for States of the Continued Presence of South Africa in Namibia (South West Africa) notwithstanding Security Council Resolution 276 (1970)

(request for advisory opinion), 5 August 1970, http://www.icj-cij.org/docket/files/53/ 9361.pdf (accessed 18 May 2007); ICJ, Legal Consequences of the Construction of a Wall in the Occupied Palestinian Territory (request for advisory opinion), 10 December 2003, http://www.icj-cij.org/docket/files/131/1497.pdf (accessed 18 May 2007).

65. Dickran Kouymjian, "La confiscation des biens et la destruction des monuments historiques comme manifestations du processus génocidaire," in L'actualité du Génocide des Arméniens. Actes du colloque organisé par le Comité de défense de la cause arménienne à Paris-Sorbonne les 16, 17 et 18 avril 1998, ed. Hrayr Henry Ayvazian, Hrair Heratchian, Hélène Kosseyan, Bernard Legras, and Claire Mouradian, 219-30 (Creteil, France: Edipol, 1999), 227.

66. On 11 August 2000, Abdelfattah Amor reported to the UN General Assembly the findings of his visit to Turkey from 30 November to 9 December 1999. His report reflects his impressions from consultations with the authorities and with NGOs and independent Turkish experts. Amor puts the prevailing intolerance in historical context: "In its relations with Europe, the Ottoman Empire had to deal with the question of its nonMuslim minorities in the context of European claims to hegemony, often expressed under the pretext of providing protection for these minorities. In these circumstances Turkish society felt itself weakened and under threat and attempted to find scapegoats within its midst, in this case the Christians ... during the first world war... when it came to the Greeks in the Aegean, the State, acting on the basis of nationalistic ideas, drove out the Greek community by instigating night-time attacks on farms, and popularized its efforts by mobilizing the Muslim religion against the Christians. After the establishment of the Republic... the State pursued this nationalistic bent, including its anti-Christian component... in particular in 1932, legislation prohibited Greeks from practicing certain professions (for example, law 2007); in 1942, a wealth tax was aimed primarily at nonMuslims, who were economically very active, in an effort to Turkicize the economy by imposing prohibitive taxes that forced people to sell their property; in 1955, anti-Christian riots broke out, apparently linked to the Cyprus issue (a bomb was placed by an official of the Ministry of the Interior at the family home of Ataturk in order, it was alleged, to provoke attacks on Christians); in 1964, as a result of tensions over the Cyprus issue, Turkey broke its agreement with Greece and prohibited all commercial dealings by Greeks holding a Greek passport, leading thereby to the departure of some 40,000 Greeks." Amor Report, paras. 62-63. In 1992 Helsinki Watch noted, "On October 11, 1964, the Turkish newspaper, Cumhuriyet, reported that 30,000 Turkish nationals of Greek descent had left permanently, in addition to the Greeks who had been expelled. The Greeks were not allowed to sell their houses or property or to take money from their bank accounts." Whitman, The Greeks of Turkey, 9.

67. The Amor Report, para. 166, recommends that "The Government should take all necessary measures, consistent with international human rights standards, to combat hatred, intolerance and acts of violence, intimidation and coercion motivated by religious intolerance."

68. In April 2005 the UN Commission on Human Rights adopted a relevant resolution: On Right to the Truth, UN CHR Resolution 2005/66, UN Doc. E/CN.4/2005/66 (20 April 2005).

69. The awkwardness of the prevailing situation can be demonstrated by a hypothetical example. How would the international community have reacted if the post-war German government had named streets after Josef Goebbels and Reinhard 
Heydrich, the architects of Kristallnacht? What would the reaction of the international community have been if, instead of making moral and material reparation, the German government had refused to render restitution and compensation to the victims and their survivors? 